\title{
Erratum: Expanding vocabulary and sight word growth through guided play in a pre-primary classroom
}

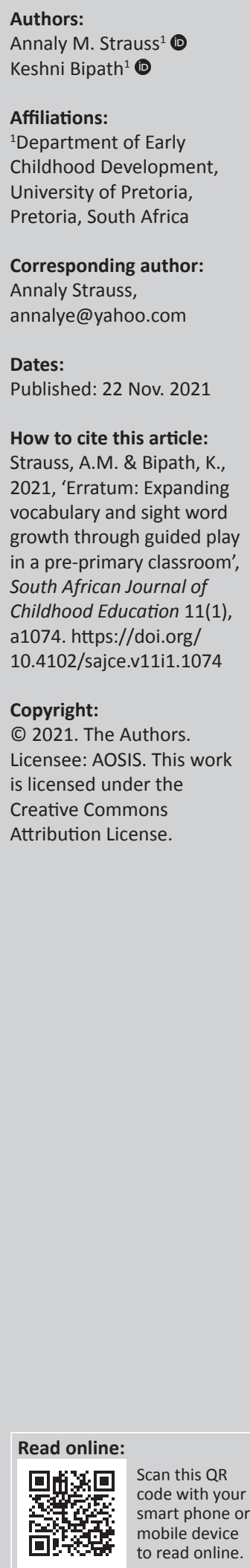

In the version of this article initially published, Strauss, A.M. \& Bipath, K., 2020, 'Expanding vocabulary and sight word growth through guided play in a pre-primary classroom', South African Journal of Childhood Education 10(1), a738. https:/ / doi.org/10.4102/sajce.v10i1.738, the first author's affiliation was given incorrectly in the 'Affiliation' section. The correct affiliation should be 'Department of Early Childhood Development, University of Pretoria, Pretoria, South Africa' instead of 'Faculty of Education, International University of Management, Windhoek, Namibia'.

This correction does not alter the study's findings of significance or overall interpretation of the study's results. The publisher apologises for any inconvenience caused. 


\section{Expanding vocabulary and sight word growth through guided play in a pre-primary classroom}

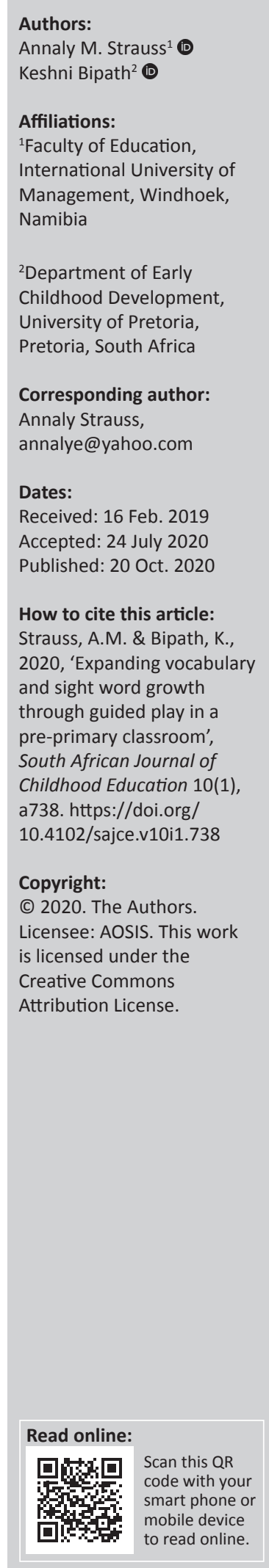

Background: This article is based on a study that aimed at finding out how pre-primary teachers integrate directed play into literacy teaching and learning. Play is a platform through which young children acquire language.

Aim: This study uses an action research approach to understand how guided play benefits incidental reading and expands vocabulary growth in a Chinese Grade K classroom.

Method: Data collection involved classroom observations, document analysis, informal and focus group discussions.

Results: The results revealed the key benefits of play-based learning for sight word or incidental reading and vocabulary development. These are: (1) teacher oral and written language learning, (2) learners' classroom engagement is promoted, (3) learners were actively engaged in learning of orthographic features of words, (4) learners practised recognising the visual or grapho-phonemic structure of words, (5) teacher paced teaching and (6) teacher assesses miscues and (7) keep record of word recognition skills.

Conclusion: In the light of the evidence, it is recommended that the English Second Language (ESL) curriculum for pre-service teachers integrate curricular objectives that promote practising playful learning strategies to prepare teachers for practice.

Keywords: guided play; cognitive development; literacy; sight word learning; explicit teaching.

\section{Introduction}

This article examines the use of directed play as a teaching and learning strategy during English Second Language (ESL) lessons in a Chinese Grade K classroom. Using a play-based strategy for teaching sight words may expand vocabulary. Play is an important vehicle for promoting language learning during early childhood and a developmentally appropriate way of teaching a range of skills and knowledge (NAEYC 2013). Playful learning refers to free play, whereas guided play is child-directed. Guided play also refers to learning experiences that combine the childdirected nature of free play with a focus on learning outcomes and adult mentorship. Guided play offers an exemplary pedagogy because it respects children's autonomy and their pride in discovery (Weisberg et al. 2016).

According to Copple and Bredekamp (eds. 2009:14), 'play is an important vehicle for developing self-regulation and for promoting language, cognition and social competence'. When young children do not gain an understanding and knowledge of the alphabet and its sound structure, the child will not be able to make connections to speak, read or write. Brown (2014:36) stated that 'learning to read is a developmental process'. According to the National Institute of Childhood Development, early reading skills can be grouped into categories with three elements: phonemic awareness, knowledge of high-frequency sight words and the ability to decode words.

Letter names and letter sounds could be taught concurrently within an early literacy lesson. Letter name knowledge is defined as the ability to recognise and identify the letters of the alphabet, whereas letter-sound knowledge refers to the ability to recognise and pronounce the sounds that represent each letter of the alphabet (Mann \& Foy 2003). For this article, sight words refer to automatic reading of high-frequency words. The article emphasises the role that the teacher can play in making play-based teaching and learning a developmental and education experience in second language classrooms.

In a comparison of Chinese and Namibian early literacy teaching and learning, the following features were prominent: (1) Chinese teachers have a monoculture, whereas the language culture 
of Namibian teachers in pre-primary learning communities differ from that of the learner and (2) basic education in China includes 3 years of compulsory preschool education (3-6 years), whereas Namibia has 1 year of preschool education (5-6 years) for those who can afford the service. Therefore, many learners may not benefit from language learning within these culturally vast and linguistically diverse environments of Namibia (Strauss \& Bipath 2018). When pre-primary learners do not understand their teachers who speak a different native tongue, they may lose out on potential language learning. Unlike teaching and learning within a Namibian early childhood context, Chinese foreign language learning environments allow young children to gain meaningful language skills. Within these language learning environments, teachers provide environment-rich materials and experiences to encourage learners to explore the environment and their ideas through play (Epstein 2014). In a study, Frolland et al. (2013); Hood, Conlon \& Andrews (2008) stated that home literacy teaching experiences are more important in developing emerging literacy skills. In the absence of these experiences, well-trained pre-primary teachers may provide literacy-rich experiences to affect children's language growth and learning positively. When teacher training prepares pre-service teachers to implement explicit play-based teaching and learning strategies it can bridge the gap that often exists between 'teachers' teaching beliefs and their classroom practices' (Strauss 2018:148).

Research argues that play and language learning go hand in hand (Zigler \& Bishop-Josef 2009). Depriving children of play denies them vital opportunities to practice important cognitive and social skills that develop their imagination and creativity (Christie \& Roskos 2000; Hirsh-Pasek et al. 2008; Pellegrini 2009). Pre-primary classroom contexts influence play activities and language learning for young children. To be particular, classroom environment and space arrangements are two key elements to enhance young children's play within the classroom context (Heidemann \& Hewitt 2010). In highly structured didactic and overcrowded early childhood classrooms the role of play, and thus language learning is at risk. Overcrowded pre-primary classes, lack of resources and untrained early childhood teachers hamper children's possibilities to benefit from language learning. There is a need for pre-service teacher training in Namibia to explore play-based teaching and language-learning strategies that can advance teachers' classroom performance under such circumstances. Teacher training provides a terrain to expand the pre-service teachers' curriculum that may strengthen teaching and learning in practice. The question of this study is: How do teachers integrate play during literacy teaching to expand sight word and vocabulary growth in pre-primary classrooms?

\section{Definition of play}

Danniels and Pyle (2018) defined play as 'an enjoyable', intrinsically motivated behaviour that is non-rule-governed, non-goal-oriented and 'just pretend'. Play-based learning results from the active engagement of a child or the interaction between the child and peers and the environment. Young children need safe spaces for social interaction to promote play-based language learning. Genishi and Dyson (2009:61) indicated that 'play is a socially complex and communicative act'. These authors highlight the benefit of play and reveal that 'young children learn from their teachers about symbols and their use to take action in childhood worlds' (p. 82). On the other hand, Hughes (2010) argued that there is not a clear definition of play. Play is both play and work. Play allows children to manipulate objects, follow prompts, and apply their minds to create new worlds. Goodman (1994) cited by Hughes (2010:8) revealed that it is at the midpoint between play and work that the best teaching occurs'. Adults design the setting to highlight a learning goal whilst ensuring that children have the autonomy to explore within that setting. Autonomy allows young children the freedom to take initiative, be persistent and creative whilst gaining language skills during guided play. Copple and Bredekamp (eds. 2009) stated that early childhood professionals who employ a literacy engaging atmosphere where developmentally appropriate practices are used prove to have thriving and successful learners.

\section{Theoretical underpinnings of play}

Research shows that play facilitates intellectual growth. Bruner (1985) and Sutton-Smith (1967) maintained that play provides a comfortable and relaxed atmosphere in which children can learn to solve a variety of real-world problems, which may be of great benefit to them. Vygotsky (1978) argued that there are several acquired and shared tools that aid in human thinking and behaviour - tools that allow for clear thinking and understanding within a specific context such as teaching guided play. These tools are provided during formal instruction, and the role of parents and teachers is critical in transmitting their knowledge and beliefs to children (Maratsos 2007). Vygotsky (1978:102) further postulated that 'to play together, children construct imaginary situations in which meanings and perceptions have a "mediated" relationship'. Bruner's (1985) theory aligned with Vygotsky's (1978) sociocultural theory in terms of the zone of proximal development (ZPD), scaffolding and learning within a social community. Play provides this social community and serves as a vehicle to advance language and literacy development. The ZPD refers to the distance between children's 'actual' and 'potential' levels of development (Vygotsky 1978). When children independently solve problems, they function at the 'actual' level of development. Justice and Ezell (2001) indicated that some children may identify all alphabet letters, whereas others know very few concepts about print (e.g. alphabet knowledge, the directionality of print, the concept of word), whereas others know a great deal. Thus, the focus of teaching within the ZPD or effectively 'scaffolding children's understanding' is centred on allocating tasks that children cannot yet accomplish on their own, but that they can accomplish within the ZPD (Vygotsky 1978). 


\section{Language and literacy development}

Hughes (2010:74) indicated that 'children are beginning to represent reality to themselves through symbols to let one thing stands for another'. When children start using a language they point to objects and people using words to name reality. Hughes (2010) termed this action 'symbolic play'. Symbolic or make-believe requires the ability to use symbols (McCune 1995 cited by Hughes 2010) and prepares young children for school literacy. Social experiences acquired through play lay the foundation for later reading and writing (DeZutter 2007 cited by Hughes 2010). When teacher training prepares pre-service teachers to use a variety of teaching and learning strategies for practice, children from diverse economic and language backgrounds may thrive in their language learning.

\section{Literacy-rich environment}

One of the characteristics of a high-quality classroom is that it exhibits an appropriate language-rich environment (Howes et al. 2008; Pianta et al. 2008; Thomason \& La Paro 2009). Children who attend quality pre-kindergarten and preprimary facilities know more letters, more letter-sound associations and are more familiar with words and book concepts than their peers who do not attend such a programme (Barnett, Larny \& Jung 2005). As the classroom's physical environment provides the foundation for literacy learning (Morrow, Tracey \& Del Nero 2011), teachers must provide the appropriate environment and materials that emphasise the importance of speaking, reading and writing. Providing space and props that focus on literacy that invites exploration, discovery and stimulates behaviours in which children and teachers are more engaged in teaching and learning activities for longer periods.

The term 'sight word' denotes to any word read automatically. High-frequency words are also known as sight words and learners should be able to read the words automatically and fluently (Brown 2014). Sight words refer to high-frequency irregularly spelt words, presumed to be impervious to decoding (Murray et al. 2019). Recognising words incidentally is important during early literacy development. Sight words stimulate learners' experiences and background so that meaning can be constructed from print. Print referencing occurs when an adult uses both verbal and non-verbal cues to guide an early reader's attention to language elements in the text. Johns and Wilke (2018) revealed that the beginning reader must learn at least 13 words at sight. These 13 words are $a$, and, for, he, in, is, it, of, that, the, to, was and you. Repeated exposure to sight words or matching pictures to text allows children to recognise orthographic patterns in words and as a result improve their sight vocabulary. According to Ehri (2014), orthographic mapping (OM) involves the formation of letter-sound connections to bond spelling, pronunciation and meaning of specific words in memory. Orthographic mapping is enabled by phonemic awareness and grapheme-phoneme knowledge. Orthographic mapping supports sight word reading and facilitates beginners to learn articulatory features of phonemes and graphemephoneme relations when letter-embedded picture mnemonics are taught. It explains how young children learn to read words by sight, spell words from memory and to acquire vocabulary words from print. Print experiences become helpful during individual reading when learners point to and track words in the text. Words should be meaningful and of interest to children to have a better understanding of the new words and what they mean for them (Johns \& Wilke 2018 cited Hans et al. 2005). According to Justice and Ezell (2004), print experiences could serve as explicit techniques when making comments or providing explanations about concepts of print and the use of elaborative questions. Young readers who master sight words by late childhood will become efficient and effective readers (Johns \& Wilke 2018).

\section{The role of the teacher}

It is the teacher's responsibility to set up the environment not by just adding words or labels, but adding meaningful print so that children can communicate and learn new information and concepts (Heroman \& Jones 2010). The intentional teacher continually assesses each child's progress and adjusts his or her strategies to meet the child's individual needs (eds. Copple \& Bredekamp 2009; Epstein 2014). In working with the teachers, Jones and Reynolds (2011) identified seven roles that teachers take on in children's play. These consist of the teacher as a 'stage manager, mediator, player, scribe, assessor, communicator and planner, observer and recorder' (Jones \& Reynolds 2011).

The 'stage manager' is the role teachers take when setting up the classroom environment to include props and materials and allow time for children to play. The role of 'mediator' is when the teacher works with children to help them solve conflicts, teaching them problem-solving skills (Jones \& Reynolds 2011). The teacher in the role of 'player', sustains play as the teacher participates in the children's play (Jones \& Reynolds 2011). As a 'scribe', 'recorder' and 'observer' the teacher to identify the children's experiences as they play can find ways to support and enhance children's play (Jones \& Reynolds 2011). As an 'assessor' and 'communicator' the teacher identifies what can be done to support children in the learning process (Jones \& Reynolds 2011).

In the role of 'player', the teacher may inhibit children's learning by interrupting the play or directing it (Jones \& Reynolds 2011). Encouraging teachers to plan for children's learning through play is not easily accepted, therefore, the role of 'assessor' and 'communicator' becomes necessary so that teachers can see how children learn as they played (Jones \& Reynolds 2011).

\section{Play-based learning}

Play-based learning approach comprises 'play as peripheral to learning' and 'play as a vehicle for social and emotional development' as opposed to having 'play as a vehicle for academic learning' (Pyle \& Bigelow 2015). When play is 
considered peripheral to learning the overall focus is on the teaching of academic skills that administration requires teachers to teach (Pyle \& Bigelow 2015). Pre-service teachers can thus benefit from instruction to guide phonemic awareness and attention to sounds in spoken words to improve children's success in learning to read through play-based strategies. Evans (2005) revealed that reading printed text involves 'multilevel processing' at a letter, word, syntactic and semantic levels. Thus, there is a pressing issue about the relationship between kinds of reading and writing fostered in pre-primary schools, children's everyday experiences and teacher training.

\section{Methodology}

This study used an action research approach to explore play-based teaching that supports young children's language and literacy development in a pre-primary classroom. 'Action research has its goal to address a specific problem within a specific setting, such as a classroom, a workplace, a program or an organisation' (Merriam 2009:4). The study highlights the use of board games as a directed play-based learning strategy. During observations, data collection solicits and documents teaching and learning strategies that promote early literacy development and how play benefits incidental reading that expands learners' vocabulary. Action research is often conducted by 'people in the real world' who are interested in practical solutions to problems and who are interested in social change (Bogdan \& Biklen 1998:234).

Data were collected using observations, documents, informal and focus group discussions. The analysis of data collected from observations, documents, informal and focus group discussions was performed using an inductive approach and critical discourse analysis. This analysis allowed for a more authentic picture of all experiences because the goal of the inductive analysis is to use the literature or a theoretical framework to anticipate themes and let them develop as the study proceeded (Corbin \& Strauss 2008). Furthermore, all lessons were video recorded and field notes were taken during the observations and focus group discussions. During these discussions, the researcher gained an understanding of Chinese teachers' teaching and learning practices. The video recordings focused on the teachers' teaching actions only. These recordings allowed the researcher to replay the teaching experiences, imagining solutions for practice, modifying ideas and reflections for action. In the analysis of documents, descriptive discourse analysis was used. Rogers (2011) indicated that print literacy practices reading and writing - are privileged in school settings and foregrounded visual modes (gaze, print) for accessing textual information through primarily paper media (Kress 2010) as revealed in the play-based activities that supported language learning. Peer reviews included informal chats and reviews of video recordings with ESL teachers. This process is known as 'member checks' (Merriam 2009) to rule out any misinterpretation of the teachers' teaching details. During repeated visits for 1 month, data were collected and a review of documentation, observations of literacy teaching to promote language and literacy development and field notes noted during informal 'chats' and focus group reviews with teachers were also included.

The ethical route to obtain permission from the school principal and participants was followed (See acknowledgement of the study). It is important to minimise any threats that included the procedures, treatments or experiences of the participants that change or threaten the researcher's ability to gather correct details or draw incorrect inferences (Creswell 2009). To ensure the validity of the research design, the researchers utilised several data collection strategies. To triangulate, we coded the data collected, using sources that include observations, documents and field notes. For a code to be valid it had to be evident in more than one data source (Merriam 2009).

\section{Participants}

This study utilised purposeful sampling to locate participants. Patton (2002:230) explained that the intention and power of this type of sample selection rest in its ability to select 'information-rich cases'. The inclusion criteria were: (1) participants must be pre-primary or pre-kindergarten teachers, (2) participants must be able to elaborate and discuss actual classroom experiences informally. Participants who met the selection criteria were identified as informationrich cases (Coyne 1997) and were selected from a larger population to be included in the sample of the study.

\section{Presentation and discussion of results}

\section{Classroom organisation and rule-setting}

The teacher used a Bingo game and flashcards to teach sight words. Bingo board games were passed out to all learners and the rules of the game were explained. Each learner received eight tokens to play with. Learners were engaged in instruction to match the word on the whiteboard with the words on the game board. The teacher encouraged limited peer interactions to allow for direct teacher contact

TABLE 1: Classroom observations.

\begin{tabular}{|c|c|c|c|}
\hline Observations & $\begin{array}{l}\text { Duration of } \\
\text { daily lessons }\end{array}$ & Research focus & Key activities \\
\hline $\begin{array}{l}24 \text { September- } \\
30 \text { October } 2018\end{array}$ & $40 \mathrm{~min}$ & $\begin{array}{l}\text { Identify teaching } \\
\text { strategies to extend } \\
\text { meaningful learning. } \\
\text { Identify the role of play } \\
\text { in teaching sight words }\end{array}$ & $\begin{array}{l}\text { 1. Classroom teaching } \\
\text { 2. Rule setting and } \\
\text { classroom } \\
\text { management } \\
\text { 3. Modelling literacy } \\
\text { practices: upper case } \\
\text { and lower-case } \\
\text { writing } \\
\text { 4. Use materials: } \\
\text { flashcards, audio and } \\
\text { visual aids } \\
\text { 5. Opportunities to } \\
\text { practice oral } \\
\text { language: identify, } \\
\text { talk or repeat words } \\
\text { 6. Analyse graphemic } \\
\text { awareness } \\
\text { 7. Modelling useful } \\
\text { strategies beyond } \\
\text { building vocabulary }\end{array}$ \\
\hline
\end{tabular}


with learners and to assess their sight word/vocabulary skills, behaviour and competence (Table 1). Whilst writing words and reading words one-by-one or using flashcards to unveil new vocabulary on the whiteboard, learners had the opportunity to match the words on the whiteboard to the words on their game boards. All learners had to figure out which words on the game board matched the words on the whiteboard (Table 1).

\section{Benefits of guided play}

Acting based on the teachers' prompts led to the discovery of word features and recognition of words rather than merely repeating words. Reading to young learners has some benefits which include - supporting the acquisition of vocabulary and literacy skills. The learner who matched the words on the whiteboard with the words on the game board first was the winner and was rewarded. Matching words encourage language learning and bring to the fore motivation in playbased learning. Learners were engaged for at least $20 \mathrm{~min}$ of the entire lesson cycle of a 40-min lesson. When time permitted, the game was played twice during the session with different sets of sight words. This allowed the teacher to pace learning new words or emphasising existing knowledge of words. During the teacher-guided play session, the ESL teacher monitored and guided play and scaffolded children's oral interactions (Table 1). At the same time, the teacher assessed learners' sight word recognition and recorded the total number of words matched correctly on a class list designed for the purpose. The learners enjoyed the game and were eager to participate and showcase their success when matching all the words (Table 1).

In the second phase of the lesson, learners practised vowel sounds [a and i] using audio soundtracks. These sounds were showcased on the whiteboard. Learners could use sight and listening skills whilst singing along, repeating letters and words, rhyming, blending and segmenting words (Table 1). Emphasis on short and long vowels and text features were pointed out. The teacher passed out worksheets with short and long sounds to analyse letter recognition. Learners were required to circle the [i]vowel in words and copy letter [a] on a worksheet (Table 1).

\section{Fieldnotes/informal discussions}

\section{Teaching and learning}

In an informal discussion, the teacher described play as an element of their day-to-day teaching process. From the comments of the teacher:

'We have ample time for outdoor and indoor play. I set out days for games or any other activity during my English lessons. The time table provides for a 10-minute free play session after each lesson and play during break times.'

From the participating teacher's assertion, it is evident that the teaching and learning process supports play. Characteristic of a quality Pre-K or Grade K program is an intellectually stimulating curriculum and highly qualified teachers (Ackerman \& Barnett 2006) that could promote sight word learning that expands vocabulary for language and literacy practice.

\section{Learning through play}

In further discussions, the teacher elaborated on play to enhance the use of language learning (Table 1). The following verbatim narrative describes guided play during language teaching:

'I do explicit teaching during my language sessions. For example, I will read a story'. [The teacher showed the book and mentioned the author and the title of the book. He noted that the learners are guided in terms of the different parts of a book]. I read the story, for example, I am red.

After the lesson, the teaching assistants move to the book corner with individual learners to re-emphasise reading for those who may have some difficulties whilst others engage in an activity to strengthen key concepts of the lesson. I teach vocabulary and sight words every day, but on special days we play a game. Like today, we played 'Bingo'. Bingo gives them a chance to master words by recognising these words automatically when they see them. Learners gain automatic word recognition skills when 'explicit instruction in phoneme segmentation along with an emphasis on the letter--sound relationships are emphasised'.

As a result, learners make larger gains in phonemic awareness than during instruction when the emphasis is on rhyming or vocabulary only (Yeh \& Connell 2008).

\section{Literacy and language curriculum}

In the analysis of data, the teacher reveals the following lesson activities (Table 1):

'I structure my classes in such a way for learners to benefit according to the topics of our curriculum. Some letters and words occur more than other words or may be confusing for the learners. In teaching alphabet knowledge, I teach two letters at a time. For example, a vowel and a consonant or two vowels at a time. This week we did [m and $\mathrm{l}$ ] and [a and i]. The good thing is, in sight words, they [the learners] learn everything.'

Research shows that pointing to and tracking words during joint reading increase print concepts and develop internalisation of word features amongst early readers (Ehri \& Sweet 1991). In using this approach towards teaching, learners gain letter knowledge automatically and as a result expand their vocabulary through play.

\section{Document analysis}

In the analysis of the documents, we used Gee's (2011) tool of data analysis for vocabulary. Kress's (2010) multimodal semiotic theory showed the boundedness of language as used on the board games and flashcards, whereas Gee's approach to discourse analysis revealed that people use language in purposeful ways, situated within social, historical and political contexts. Utterances in Figures 1-5 focus on English communication and words that are used 
and which contribute to communication in terms of 'style'. (See findings in the discussion of results.)

Figure 1 portrays the different Bingo games. A game set comprises six different boards with eight different sight words and a missing word on each board.

Figures 2 and 3 comprise of the call-out words. Eighteen words were called-out and written on the whiteboard (See Figure 3: Sight words). Learners first had to recognise the written word on a word card and match that card with the corresponding word only on the game board or flashcard. They searched for the word card that rhymed and connected it to the target word, again followed by the matching word only. The words were written down or called-out to create a challenge for the learners to match them.

The visuals (Figures 4 and 5) portray how audio-visuals were used in the literacy-related activity during the 40-min class time. Both vowels [a and i] were taught in the same way. Learners had the opportunity to watch the video and sing along to practise oral language and to emphasise letter knowledge and phonics-based on the Bingo game. Developing letter knowledge, letter names and letter sounds is an important factor in the development of phonemic awareness (Carrol 2004). Learning letter names and sounds teach children the alphabetic principle. Learners watched pictures of stimuli and heard an accompanying word through the audio-visual presented to them. When children know sounds, they can mentally search to see if a heard sound is associated with a letter sound he or she knows (Carrol 2004). The use of audio lessons emphasises alphabet knowledge and phonemic awareness to expand letter knowledge and increase vocabulary.

Figure 4 shows the activity in which letter [a] was omitted. Learners practised writing and copied letter [a] on the worksheet (Literacy activity).

\section{Ethical consideration}

Ethical clearance was granted by the University of Pretoria, EC 16/08/01.

\section{Discussion of results}

This action research study examined language and literacy development through guided play. The data were collected

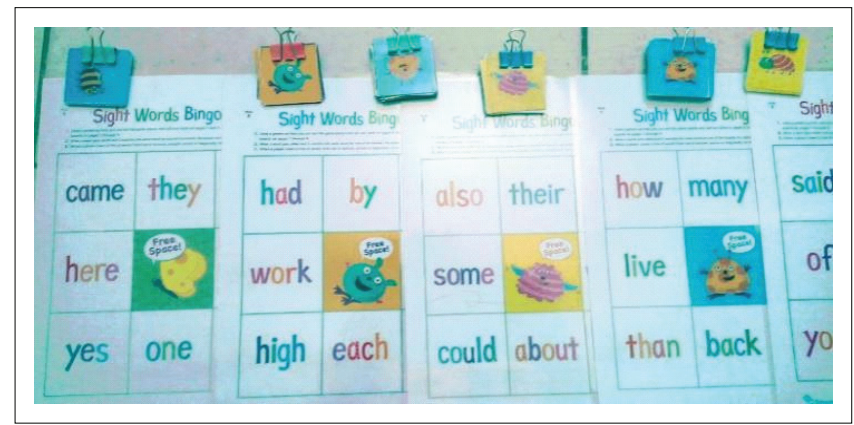

Note: Bingo games - sight words.

FIGURE 1: Bingo game. during September - October 2018 from literacy teaching sessions in Chinese ESL Pre-K and Grade K settings. Even though the researcher has observed a Pre-K and Grade K classroom, we gained useful insight from the Grade K classroom. These observations were language richer and longer than those in the pre-kindergarten classroom, where lessons were shorter and comprised of mostly artwork and singing. Pre-K classrooms comprised of 3-4-year-old children and the Grade K's were 5-6 years old. Classrooms comprised of 10-12 learners, a homeroom teacher, ESL teacher and two ESL teaching assistants in each classroom. Classrooms are well-equipped with a whiteboard, computer and monitor amongst other equipment. Several opportunities, using

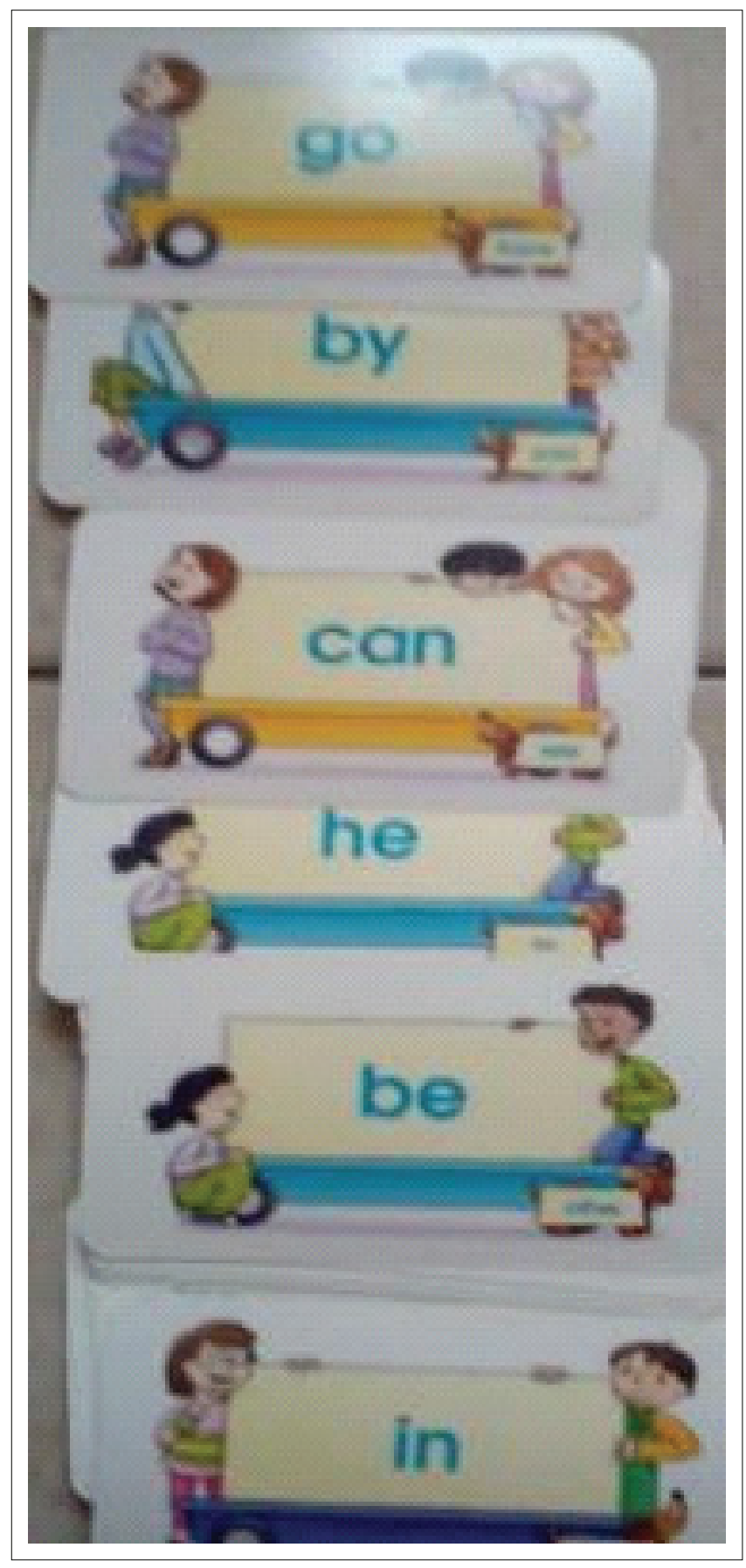

FIGURE 2: Flashcards. 


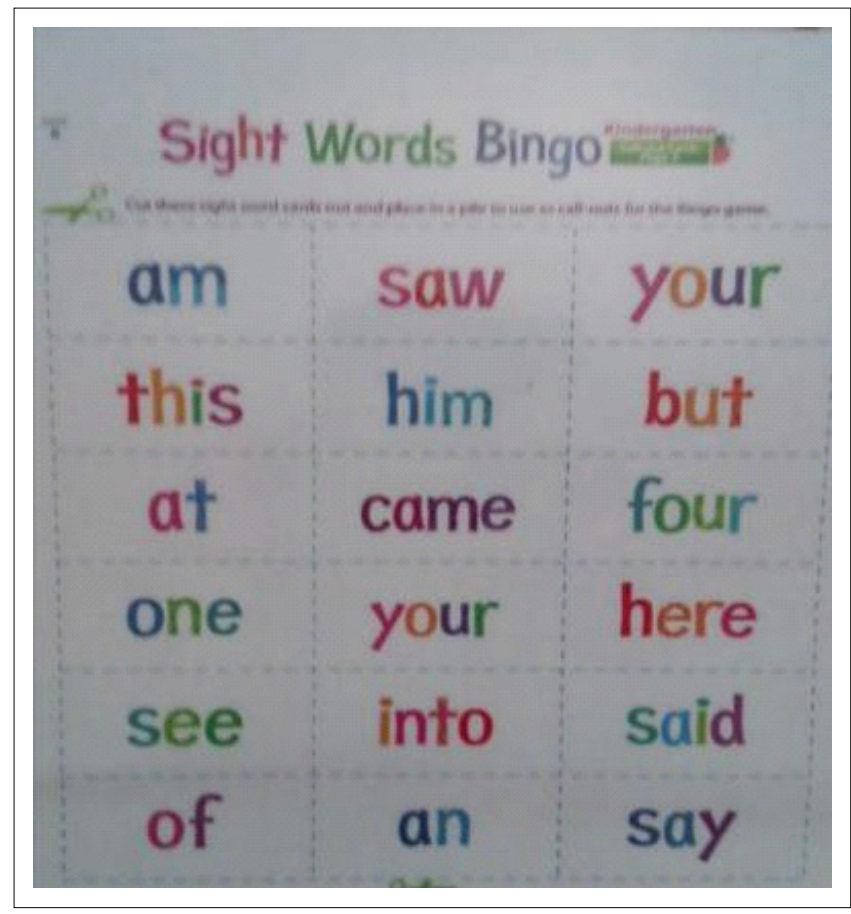

FIGURE 3: Sight words.

multimodal media are afforded for innovative teaching practice. Materials are readily available for learners and teachers' use.

The evidence shows that guided play promotes learners' discovery of letter properties, exploring cueing letters and decoding words based on the words of the game board. Efficient decoding of words is necessary for reading comprehension in all grades (Verhoeven \& Van Leeuwe 2008). Learners showed great enthusiasm when matching letters and words on the game board. Riley and Jones (2012:4) stated '[...] primary-age children need time to hear new vocabulary and experiment with the language in order to build their understanding of the ways language works'. Individual monitoring of learners matching words, completing an activity, revealed advance letter knowledge and phonological awareness. When teachers guide learners on how to use words correctly, introduce new words and ways to speak, young children begin to better understand the language modelled correctly for them through guidance whilst engaging themselves in play. The results revealed the features of teaching and unique benefits of play-based learning to enhance sight word recognition and vocabulary development. These are: (1) teachers model oral and written language learning, (2) learners classroom engagement is promoted, (3) learners were actively engaged in cognitive learning of orthographic features of words, (4) learners practised recognising the visual/grapho-phonemic structure of words, (5) teacher paced teaching (6) teacher assesses miscues and keeps a record of word recognition skills. Engagement through play-based learning allows the teacher to scaffold learners who may find it difficult to recognise sight words, follow instructions or struggle to pay attention. Play is a platform through which young learners acquire language.

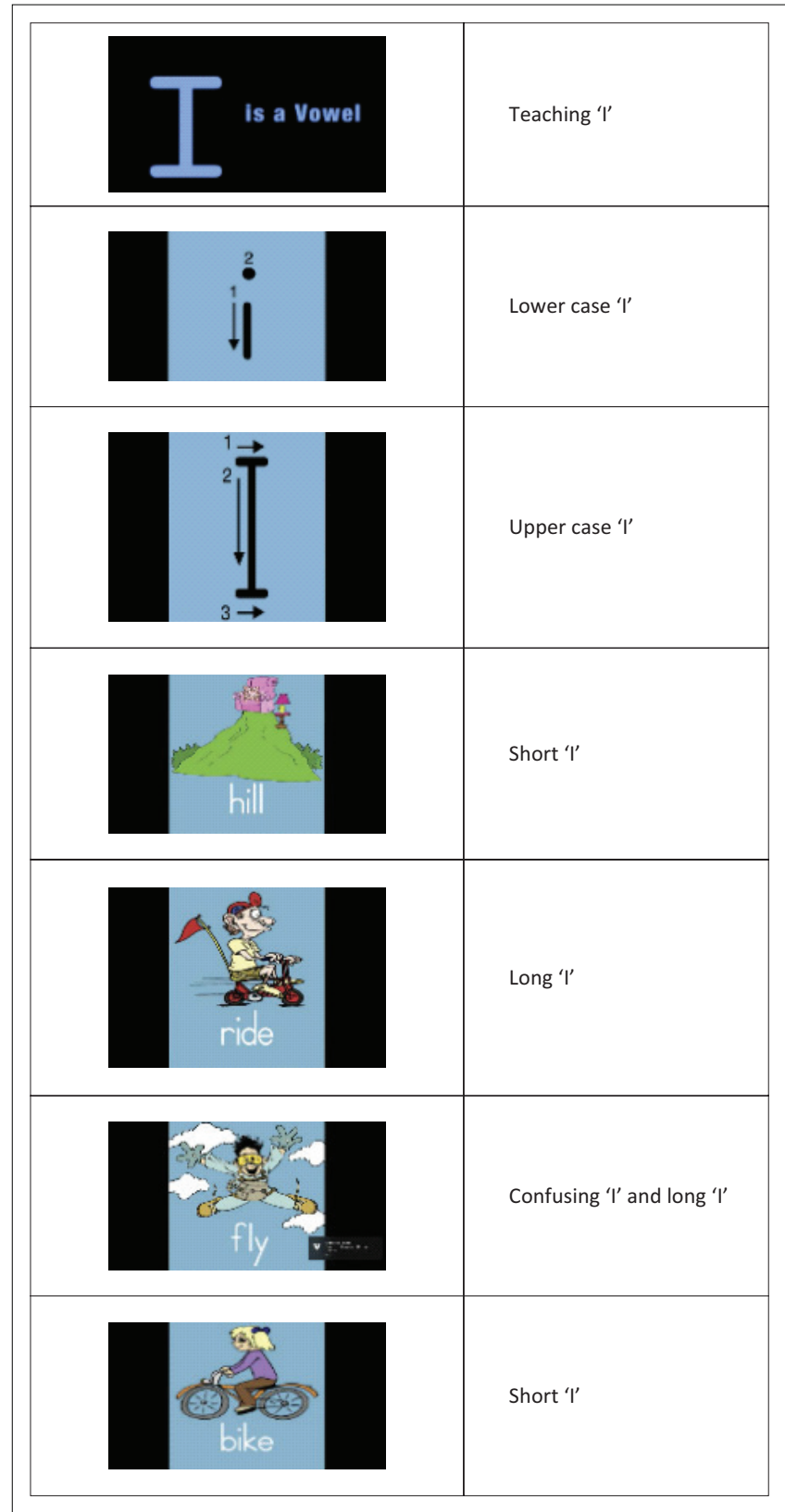

FIGURE 4: Vowel [i].

A playful review of new vocabulary items differs substantially from the didactic teaching methods commonly used in preschool classrooms (Early et al. 2008). Learners' active participation in guided play gave teachers' the opportunity to scaffold them towards the understanding of important symbols and letter concepts as well as assessing and recording their word recognition progress. Data collected from the observations and document analysis reveal useful strategies to systematically help teachers to identify ESL learners' phonological difficulties and interferences as a result of their native/first language to develop literacy and language skills during the early phase of learning.

The researcher noted the teachers' perspectives during informal discussions. The results of informal discussions reveal that teachers practice explicit teaching for sight word learning that promotes literacy development. The 'lack of 
training in teaching second languages is a serious weakness of teacher education in many developing countries' (Eisemon 1992:37) such as Namibia. The Chinese Pre-K and Grade K curriculum provide ample time for both indoor and outdoor play. Strauss (2018) cited Justice et al. (2003) who showed that increased learner's participation in classroom-based literacy experiences characterised by explicit and purposeful experiences with print and sound can accelerate emergent literacy development. When Namibian teachers are trained to use alternative teaching strategies to enhance language and literacy development, more learners from diverse language backgrounds may benefit from explicit teaching. Justice et al. (2012) showed that:

$[H]$ igh-quality literacy instruction features systematic and explicit direct instruction that teaches children about code-based characteristics of written language to include both phonological and print structures. (p. 53)

The multimodal analysis of Figures 1-5 shows how the participating teachers created socially constructed meaning when using game boards, call-out words, used multimedia and activity to facilitate learning through play. The multimodal analysis involves isolating, examining and explaining aspects of the teachers' instructional strategy to understand how the teacher and students use the available semiotic resources to represent the meaning of language.

The learners listened and related the teacher's oral account of the word to words on the game board. They also handled tokens on the board game whilst teachers observed and engaged orally, scaffolded and uncovered new words repeatedly during directed play. Learning sight words were mediated by material resources (See Figures 1-5) and other social actors within the cultural practice of school (Rogers 2011). Teacher training in Namibia can play a pivotal role to enhance pre-service teachers' teaching skills to benefit children's reading.

\section{Recommendations for further research}

This study recommends further research to examine guided play within a Namibian context. Based on this comparative analysis, this study recommends that teacher training in Namibia prepares teachers to become better skilled at engaging

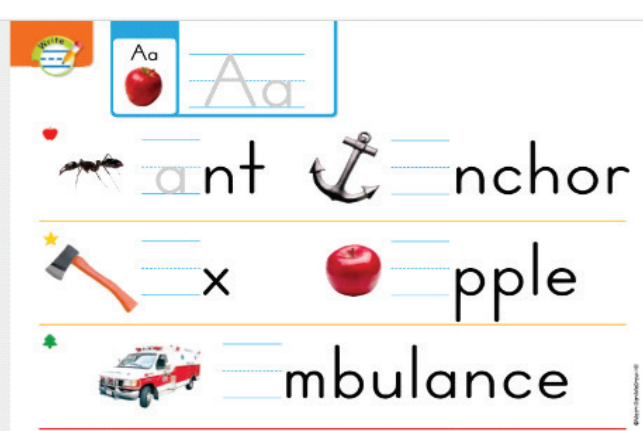

FIGURE 5: Vowel [a]. learners in pre-primary settings to elicit their ideas through play-based teaching and learning when using alternative teaching strategies and monitoring literacy progress.

\section{Acknowledgements}

The $\mathrm{PhD}$ thesis was submitted to the University of Pretoria under the supervision of Dr Keshni Bipath.

\section{Competing interests}

The authors declare that no competing interests exist.

\section{Authors' contributions}

A.M.S. and K.B. performed data collection, analysis and editing.

\section{Funding information}

The study was made possible with the generous financial support of Bethel International Organisation in California, United States. The study was conducted in the Bethel International School, Zhengzhou, Henan Province of China and the DHET/EU funding, University of Pretoria.

\section{Data availability statement}

Data sharing is not applicable to this article as no new data were created or analysed in this study.

\section{Disclaimer}

The authors declare that the work is their own and that it was written in their own words. All citations from literature is acknowledged in-text and referenced. We agree that subject to the ownership of all intellectual property rights in this work, the approved version of this work may be published by the South African Journal of Early Childhood Education under our authorship.

\section{References}

Barnett, W., Lamy, C. \& Jung, K., 2005, The effects of state prekindergarten programs on young children's school readiness in five states, National Institute for Early Education Research, New Brunswick, NJ.

Bogdan, R.C. \& Biklen, S.K., 1998, Qualitative research in education, 3rd edn., Allyn \& Bacon, Boston, MA.

Brown, C.S., 2014, 'Language and literacy development in the early years: Foundational skills that support emergent readers', Language and Literacy Spectrum 24(1), 35-49.

Bruner, J.S., 1985, 'Early social interaction and language acquisition', in H.R. Schaffer (ed.), Studies in mother-infant interaction, Academic Press, London.

Carrol, J.M., 2004, 'Letter knowledge precipitates phoneme segmentation, but not phoneme invariance', Research in Reading 27(3), 212-225. https://doi.org/10. 1111/j.1467-9817.2004.00228.x

Christie, J.F. \& Rokos, K.A., 2000, Play and literacy in early childhood: Research from multiple perspectives, LEA, London.

Copple, C. \& Bredekamp, S. (eds.), 2009, Developmentally appropriate practice in early childhood programs serving children from birth through age 8, 3rd edn., NAEYC, Washington, DC.

Corbin, J. \& Strauss, A., 2008, Basics of qualitative research: Techniques and procedures for developing grounded theory, Kindle edition, Sage, Thousand Oaks, CA.

Coyne, I.T., 1997, 'Sampling in qualitative research. Purposeful and theoretical sampling; merging or clear boundaries?', Journal of Advanced Nursing 26(3), 623-630. https://doi.org/10.1046/j.1365-2648.1997.t01-25-00999.x

Creswell, J.W., 2009, Research design, 3rd edn., Sage, Thousand Oaks, CA. 
Danniels, E. \& Pyle, A., 2018, 'A continuum of play-based learning: The role of the teacher in play-based pedagogy and the fear of hijacking play', Early Education teacher in play-based pedagogy and the fear of hijacking play', Early Education
and Development 28(3), 274-289. https://doi.org/10.1080/10409289.2016. and Develor

Early, D., Barbarin, O., Bryant, D., Burchinal, M., Clifford, R., Howes, C. et al., 2008, 'Ready to learn? Children's pre-academic achievement in pre-kindergarten programs.' Early Childhood Research Quarterly 23(1), 27-50. https://doi. programs.' Early Childhood Resear

Ehri, L.C. \& Sweet, J., 1991, 'Finger point-reading of memorized text: What enables beginners to process the print?', Reading Research Quarterly 24(4), 442-462. https://doi.org/10.2307/747897

Ehri, L.C., 2014, 'Orthographic mapping in the acquisition of sight word reading, spelling memory, and vocabulary learning', Scientific Studies of Reading 18(1), 5-21. https://doi.org/10.1080/10888438.2013.819356

Eisemon, T.O., 1992, 'Private initiatives in higher education in Kenya', Higher Education 24(2), 157-175. https://doi.org/10.1007/BF00129439

Epstein, A.S., 2014, The intentional teacher: Choosing the best strategies for young children's learning, National Association for the Education of Young Children, Washington, DC

Evans, J., 2005, Literacy moves on: Popular culture, new technologies and critical literacy in the elementary classroom, Heineman, Portsmouth, $\mathrm{NH}$.

Frolland, J., Powell, D., Diamond, K. \& Son, S., 2013, 'Neighbourhood socio-economic well-being, home literacy, early literacy skills of at-risk preschoolers', Psychology in Schools 50(8), 755-769. https://doi.org/10.1002/pits.21711

Gee, J.P., 2011, How to do discourse analysis: A toolkit, 2nd edn., Routledge, New York, NY

Genishi, C. \& Haas Dyson, A., 2009, Children, language and literacy: Diverse learners in diverse times, Teachers College Press, New York, NY.

Heidemann, S. \& Hewitt, D., 2010, Play the pathway from theory to practice, 2nd edn., Redleaf Press, St. Paul, MN.

Heroman, C. \& Jones, C., 2010, The creative curriculum for preschool, vol. 3, Literacy, Teaching Strategies, Washington, DC.

Hirsh-Pasek, K., Golinkoff, R.M., Berk, L.E. \& Singer, D.G., 2008, A mandate for playful learning in preschool, Presenting the Evidence, Oxford University Press, New York, NY.

Hood, M., Conlon, E. \& Andrews, G., 2008, 'Preschool home literacy practices and children's literacy development: A longitudinal analysis', Journal of Educationa Psychology 100(2), 252-271. https://doi.org/10.1037/0022-0663.100.2.252

Howes, C., Burchinal, M., Pianta, R., Bryant, D., Early, D., Clifford, R. et al., 2008, 'Ready to learn? Children's pre-academic achievement in pre-kindergarten programs' Early Childhood Research Quarterly 23(1), 27-50. https://doi.org/10.1016/j ecresq.2007.05.002

Hughes, F.P., 2010, Children, play, and development, 4th edn., Sage, United Kingdom.

Johns, J.L. \& Wilke, K.H., 2018, 'High-frequency words: Some ways to teach and help students practice and learn them', Texas Journal of Literacy Education 6(1), 1-13.

Jones, E. \& Reynolds, G., 2011, 'The play's the thing: Teachers' roles in children's play', Teachers College Press, New York, NY.

Justice, L.M. \& Ezell, H.K., 2001, 'Written language awareness in preschool children from low-income households: A descriptive analysis', Communication Disorders Quarterly 22(3), 123-134. https://doi.org/10.1177/152574010102200302

Justice, L.M. \& Ezell, H.K., 2004, 'Print referencing: An emergent literacy enhancement technique and its clinical applications', Language, Speech, and Hearing Services 35(2), 185-193. https://doi.org//10.1044/0161-1461(2004/018)

Justice, L.M., Chow, S., Capellini, C., Flanigan, K. \& Calton, S., 2003, 'Emergent literacy intervention for vulnerable preschoolers: Relative effects of two approaches', American Journal of Speech Pathology, 12, 220-232. American Speech-LanguageHearing Association 1058-0360/03/1203-032.
Kress, G., 2010, Multimodality: A social semiotic approach to contemporary communication, Oxford, Routledge.

Mann, V.A. \& Foy, J.G., 2003, 'Phonological awareness, speech development, and letter knowledge in preschool children', Annual of Dyslexia 53(1), 149-173. https://doi.org/10.1007/s11881-003-0008-2

Maratsos, M.P., 2007, 'Commentary. Monographs of society for research in child development', Research in Child Development 72(1), 121-126.

Merriam, S.B., 2009, Qualitative research: A guide to design and implementation, Jossey-Brass, California, CA.

Morrow, L., Tracey, D. \& Del Nero, J., 2011, 'Best practices in early literacy: Preschool, kindergarten and first grade', in L. Morrow \& L. Gambrell (eds.), Best practices in literacy instruction, 4th edn., pp. 67-95, The Guilford Press, New York.

Murray, B.A., Mcllwain, M.J., Wang, C., Murray, G. \& Finley, S., 2019, 'How do beginners learn to read irregular words as sight words?', Journal of Research in Reading 42(1), 123-136. https://doi.org/10.1111/1467-9817.12250

National Association for the Education of Young Children (NAEYC), 2013, Developmentally appropriate practice guidelines: Position statement, NAEYC, Washington, DC

Patton, M.Q., 2002, 'Designing qualitative studies', Qualitative Research and Evaluation Methods 3(1), 230-246.

Pellegrini, A.D., 2009, 'The role of play in human development', Oxford University Press, Oxford, UK.

Pianta, R.C., Mashburn, A.J., Downer, J.T., Hamre, B.K. \& Justice, L., 2008, 'Effects of web-mediated professional development resources on teacher-child interactions in pre-kindergarten classrooms', Early Childhood Research Quarterly 23(4), 431-451. https://doi.org/10.1016/j.ecresq.2008.02.001

Pyle, A. \& Bigelow, A., 2015, 'Play in kindergarten: An interview and observational study in three Canadian classrooms', Early Childhood Education 43(7), 385-393. https://doi.org/10.1007/s10643-014-0666-1

Riley, J.G. \& Jones, R.B., 2012, 'Acknowledging learning through play in the primary grades', Childhood Education 86(3), 146-149. https://doi.org/10.1080/00094056. grades', Childhood

Rogers, R., 2011, Critical discourse analysis in education, 2nd edn., Taylor and Francis, New York, NY.

Strauss, A.M. \& Bipath, K., 2018, 'Parents' print and digital reading behaviours to support emergent literacy', SAALT, Unpublished.

Strauss, A.M., 2018, 'A dialogical approach for improving early literacy teaching in multilingual pre-primary contexts', PhD dissertation, University of Pretoria.

Sutton-Smith, B., 1967, 'The role of play in cognitive development', Young Children 22(1), 361-370.

Thomason, A.C. \& La Paro, K.M., 2009, 'Measuring the quality of teacher-child interactions in toddler child care', Early Education \& Development 20(2), 285-304. https://doi.org/10.1080/10409280902773351

Verhoeven, L. \& Van Leeuwe, J., 2008, 'A prediction of the development of readin comprehension: A longitudinal study', Applied Cognitive Psychology 22(3), 407-423. https://doi.org/10.1002/acp.1414

Vygotsky, L.S., 1978, Mind in society: The development of higher psychological processes, Harvard University Press, Cambridge, MA

Weisberg, D.S., Hirsh-Pasek, K., Golinkoff, R.M., Kittredge, A.K. \& Klahr, D., 2016, 'Guided play: Principles and practices', Association for Psychological Science 25(3), 177-182. https://doi.org/10.1177/0963721416645512

Yeh, S. \& Connell, D., 2008, 'Effects of rhyming, vocabulary and phonemic awareness instruction on phoneme awareness', Journal of Research in Reading 31(2), 243-256. https://doi.org/10.1111/j.1467-9817.2007.00353.x

Zigler, E.F. \& Bishop-Josef, S.J., 2009, 'Play under siege', A historical overview, Zero to three Journal 30(1), 4-11. 